BMJ Open

Diabetes

Research

\& Care

\title{
Evaluation of vitamin D relationship with type 2 diabetes and systolic blood pressure
}

\author{
Shivananda Bijoor Nayak, Terry Gavaskar Ramnanansingh
}

To cite: Nayak SB, Ramnanansingh TG. Evaluation of vitamin $D$ relationship with type 2 diabetes and systolic blood pressure. BMJ Open Diabetes Research and Care 2016:4:e000285. doi:10.1136/bmjdrc-2016000285

Received 20 June 2016 Revised 19 August 2016 Accepted 5 September 2016

\section{ABSTRACT}

Objective: To investigate whether relationships exist among vitamin D, type 2 diabetes mellitus (T2DM), and blood pressure in Trinidadian subjects with T2DM.

Research design and methods: This was a casecontrolled study to determine if vitamin $D$ levels were lower in patients with T2DM. After data analysis, an exploratory hypothesis of vitamin $D$ relationship to systolic blood pressure (SBP) was developed. Plasma calcifediol $(25(\mathrm{OH}) \mathrm{D})$ concentrations were used as a measurement for vitamin $D$ levels and were determined by ELISA. Cholesterol levels were measured by an automated dry chemistry analyzer and blood pressure was measured using an automatic blood pressure monitor.

Results: There was no significant difference $(p=0.139$, $\mathrm{n}=76$ ) in 25(OH)D levels between patients with T2DM and controls. Subjects with SBP above $130 \mathrm{~mm} \mathrm{Hg}$ were 8 times more likely to have a $25(\mathrm{OH}) \mathrm{D}$ plasma concentration above $25 \mathrm{ng} / \mathrm{mL}$ (OR 7.9 (2.2 to 28.7)), and were 5 times (OR 4.7 (1.7 to 15.1)) more likely to have a $25(\mathrm{OH}) \mathrm{D}$ plasma concentration above $30 \mathrm{ng} / \mathrm{mL}$ (OR 7.5 (2.3-24.2)). Vitamin D levels moderately and positively correlated with SBP $\left(r_{s}=0.38, p=0.001\right)$.

Conclusions: There was no significant difference in the 25(OH)D levels between patients with T2DM and controls $(p=0.139)$. Patients with SBP under

$130 \mathrm{~mm} \mathrm{Hg}$ were 8 times more likely to have a vitamin D level above $25 \mathrm{ng} / \mathrm{mL}$ (OR 7.9 (2.2 to 28.7)). Further investigations are required to examine the relationship between vitamin $\mathrm{D}$ and SBP.

\section{INTRODUCTION}

Vitamin D is well known for its role in calcium and bone metabolism; however, its deficiency may play a role in type 2 diabetes mellitus (T2DM). ${ }^{1}$ The exact pathogenesis of T2DM remains unknown, but the condition is a result of different environmental and biochemical factors. ${ }^{2}$ It is important then to look at different biochemical components to determine their role in T2DM. The biochemical component that is of particular interest in this study is vitamin D.

Cholecalciferol (vitamin $\mathrm{D}_{3}$ ) is photosynthesized from 7-dehydroxycholecalciferol within the epidermal layer of the skin. When

\section{Significance of this study}

What is already known about this subject?

- An unclear relationship between type 2 diabetes mellitus (T2DM) and the vitamin D axis.

- Vitamin $D$ levels are lower in hypertensive individuals as compared with normotensive individuals.

What are the new findings?

- Vitamin $D$ levels are higher in patients with systolic blood pressure (SBP) above $130 \mathrm{~mm} \mathrm{Hg}$ as compared with patients with SBP lower than $130 \mathrm{~mm} \mathrm{Hg}$.

How might these results change the focus of research or clinical practice?

- Future studies of vitamin $D$ relationship to blood pressure and T2DM need to be conducted in tropical regions since vitamin $D$ is regarded as a 'sunshine vitamin'.

ultraviolet B (UVB) radiation from a source such as the sun strikes the skin, 7dehydroxycholecalciferol transforms into vitamin $\mathrm{D}_{3} .{ }^{3}{ }^{4}$ Vitamin $\mathrm{D}_{3}$ undergoes hydroxylation in the liver to form calcifediol (25-hydroxyvitamin D). Calcifediol $(25(\mathrm{OH})$ D) is further hydroxylated in the kidneys to form calcitriol (active form of vitamin D). Calcitriol (1,25-dihydroxyvitamin $\left.\mathrm{D}_{3}\right)$ mediates its metabolic effect by binding to the Vitamin D Receptor (VDR) found inside the cell. ${ }^{5}$ Calcitriol $\left(1,25(\mathrm{OH})_{2} \mathrm{D}\right)$ has a half-life of $\sim 4$ hours, so it is not effective in reflecting the overall vitamin D status of humans. ${ }^{6} 25$ $(\mathrm{OH}) \mathrm{D}$ has a minimal circulating half-life of 2 months since it can be stored and released from adipose and muscle tissue. ${ }^{7} 8$ For the purposes of this study, $25(\mathrm{OH}) \mathrm{D}$ will be used to reflect the subjects' vitamin D levels.

All study participants are from the Caribbean, in the country of Trinidad $\left(10.6667^{\circ} \mathrm{N} ; 61.5167^{\circ} \mathrm{W}\right)$, which generally has a warm and sunny climate throughout the year. The study participants generally have skin type $\mathrm{V}$ (brown) according to the Fitzpatrick $^{9}$ classification of skin type. It is expected that most study participants 
experience sufficient sunlight which can result in participants having sufficient levels of $25(\mathrm{OH}) \mathrm{D}^{10}{ }^{11}$ If a patient normally remains indoors, synthesis of vitamin $\mathrm{D}_{3}$ from sunlight will be low but vitamin $\mathrm{D}$ can be obtained from fish, eggs, and vitamin D fortified milk. ${ }^{10}$ Vitamin $\mathrm{D}$ deficiency and insufficiency are characterised as $25(\mathrm{OH}) \mathrm{D}<20$ and $21-29 \mathrm{ng} / \mathrm{mL}$, respectively. ${ }^{6}$

Studies have shown that T2DM and hypertension are related $;{ }^{12-14}$ however, $25(\mathrm{OH})$ D's relation to blood pressure (BP) is unclear and the literature surveyed for 25 $(\mathrm{OH}) \mathrm{D}$ and $\mathrm{BP}$ gave conflicting reports of this relationship. ${ }^{10}{ }^{11}{ }^{15}$ In this study, it was hypothesized that 25 $(\mathrm{OH}) \mathrm{D}$ levels were significantly lower in patients with T2DM and systolic BP (SBP) over $130 \mathrm{~mm} \mathrm{Hg}$.

\section{RESEARCH DESIGN AND METHODS}

Ethical approval to conduct the study was obtained from the University of the West Indies (UWI), St. Augustine, the South West Regional Health Authority (SWRHA), and the North Central Regional Health Authority (NCRHA) in Trinidad and Tobago. Subjects were randomly chosen at the Eric Williams Medical Sciences Complex (EWMSC) and San Fernando General Hospital (SFGH) in Trinidad. The sample size chosen for the study was 80 because of limitations in resources for assays. Both effect size and sample size with $80 \%$ power were estimated for future studies.

Hospital records were used to select at random patients who were diagnosed with T2DM. From the hospital records, patients with T2DM had a history of having glycated hemoglobin (HbA1c) and fasting blood glucose (FBG) values of $\geq 6.5 \%$ and $\geq 120 \mathrm{mg} / \mathrm{dL}$, respectively. Clinicians at the SFGH and the EWMSC screened patients with T2DM again, to ensure that the patients did have the condition of T2DM before they were allowed to participate in the study. Controls were selected from the hospitals at random and were included in the study provided that the controls did not fall into the exclusion criteria. Antihypertensive drugs used and information on kidney disorders were recorded. The exclusion criteria for both controls and patients with T2DM were: persons consuming more than $8 \mathrm{~mL}$ of ethanol per week; taking multiple antihypertensive medications; having any form of cancer or any condition that may raise inflammatory markers; having T1DM; having any form of liver disease; having thyroid or parathyroid problems; being pregnant; and being under the age of 18. Additionally, exclusion criteria for controls only were HbAlc or FBG values of $\geq 6.5 \%$ or $\geq 120 \mathrm{mg} / \mathrm{dL}$, respectively.

Subjects fasted and did not take any medication 8-10 hours before venous blood samples were drawn. On the morning of the blood draw, before venous samples were taken, the subjects' height and mass were measured. SBP and diastolic BP (DBP) were measured using a digital BP monitor. Venous blood samples drawn into blood collection tubes were centrifuged at $2000 \mathrm{~g}$ and separated into serum and plasma fractions. All blood fractions and two whole blood samples were stored at $-70^{\circ} \mathrm{C}$ subsequent to analysis. Plasma $25(\mathrm{OH})$ D was determined by ELISA (ADI-900-215, Enzo Life Sciences, USA). Serum cholesterol was assayed using an automated dry chemistry analyzer (Cobas 6000, Roche Diagnostics, USA). Four subjects were removed from the study because of blood sample hemolysis. The final sample size for the study was 76 subjects (24 males and 52 females).

Software packages used for statistical analyses were IBM SPSS Statistics V.21, Minitab 16, and G*Power 3.1.7. Statistical analyses performed were Anderson-Darling test, independent t-test, Mann-Whitney U-test, Fisher's exact test, Spearman's correlation $\left(r_{s}\right)$, logistic regression, and general linear model (GLM) univariate

Table 1 Demographic details of study sample

\begin{tabular}{|c|c|c|c|c|c|}
\hline Parameter & $\begin{array}{l}\text { All subjects, } \\
\mathrm{n}=76(\%)\end{array}$ & $\begin{array}{l}\text { Controls, } \\
\mathrm{n}=35(\%)\end{array}$ & $\begin{array}{l}\text { Patients with } \\
\text { T2DM, } n=41 \text { (\%) }\end{array}$ & $\begin{array}{l}25(O H) D>25 \\
\mathrm{ng} / \mathrm{mL}, \mathrm{n}=58(\%)\end{array}$ & $\begin{array}{l}25(O H) D \leq 25 \\
\mathrm{ng} / \mathrm{mL}, \mathrm{n}=18(\%)\end{array}$ \\
\hline \multicolumn{6}{|l|}{ Age, years } \\
\hline $40-50$ & $15(20)$ & $12(34)$ & $4(10)$ & $13(22)$ & 7 (39) \\
\hline $51-70$ & $51(67)$ & $18(52)$ & $32(78)$ & $34(59)$ & $10(55)$ \\
\hline $70-80$ & $10(13)$ & $5(14)$ & 5 (12) & $11(19)$ & $1(6)$ \\
\hline \multicolumn{6}{|l|}{ Ethnicity } \\
\hline East Indian & $43(56)$ & $16(46)$ & $27(66)$ & $31(53)$ & $12(67)$ \\
\hline African & $22(29)$ & $14(40)$ & 8 (19) & $20(35)$ & $2(11)$ \\
\hline Mixed & $11(15)$ & 5 (14) & $6(15)$ & 7 (12) & $4(22)$ \\
\hline \multicolumn{6}{|l|}{ BMI, $\mathrm{kg} / \mathrm{m}^{2}$} \\
\hline$<25$ & $15(20)$ & $10(29)$ & 5 (12) & $11(19)$ & $4(22)$ \\
\hline $25-30$ & $26(34)$ & $11(31)$ & $15(37)$ & 19 (33) & 7 (39) \\
\hline$>30$ & $35(46)$ & $14(40)$ & $21(51)$ & $28(48)$ & 7 (39) \\
\hline $\begin{array}{l}\text { Subjects on antihypertensive } \\
\text { medication }\end{array}$ & $40(53)$ & $15(43)$ & $25(61)$ & $33(57)$ & 7 (39) \\
\hline Kidney disease & $7(9)$ & $5(14)$ & $2(5)$ & $7(12)$ & $0(0)$ \\
\hline
\end{tabular}

BMI, body mass index; T2DM, type 2 diabetes mellitus. 
Table 2 Characteristics of the variables in study in relation to T2DM

\begin{tabular}{|c|c|c|c|c|c|c|c|c|}
\hline \multirow[b]{2}{*}{ Variable } & \multicolumn{3}{|l|}{ Mean+SD } & \multirow[b]{2}{*}{ Distribution } & \multirow[b]{2}{*}{$\begin{array}{l}\text { Test } \\
\text { statistic }\end{array}$} & \multirow[b]{2}{*}{$\begin{array}{l}p \\
\text { Value }\end{array}$} & \multirow[b]{2}{*}{$\begin{array}{l}\text { Effect } \\
\text { sized }\end{array}$} & \multirow[b]{2}{*}{$\begin{array}{l}\text { Sample size } \\
\text { estimate, } 80 \% \\
\text { power }\end{array}$} \\
\hline & $\begin{array}{l}\text { Total } \\
(n=76)\end{array}$ & $\begin{array}{l}\text { Controls } \\
(n=35)\end{array}$ & $\begin{array}{l}\text { Patients with } \\
\text { T2DM }(n=41)\end{array}$ & & & & & \\
\hline Age (years) & $58.9 \pm 9.6$ & $57.7 \pm 10.8$ & $59.8 \pm 8.6$ & Normal & $\mathrm{t}$ & 0.375 & 0.2 & 792 \\
\hline BMI $\left(\mathrm{kg} / \mathrm{m}^{2}\right)$ & $30.2 \pm 6.8$ & $29.1 \pm 6.5$ & $31.1 \pm 7.0$ & 3P-Weibull & $U$ & 0.293 & 0.3 & 410 \\
\hline $\mathrm{SBP}(\mathrm{mm} \mathrm{Hg})$ & $145.6 \pm 22.7$ & $141 \pm 20$ & $149.8 \pm 24.2$ & Normal & $\mathrm{t}$ & 0.095 & 0.4 & 200 \\
\hline $\mathrm{DBP}(\mathrm{mm} \mathrm{Hg})$ & $87.7 \pm 10.8$ & $87 \pm 11$ & $88.3 \pm 10.9$ & Normal & $\mathrm{t}$ & 0.598 & 0.1 & 3162 \\
\hline $25(\mathrm{OH}) \mathrm{D}(\mathrm{ng} / \mathrm{mL})$ & $38.3 \pm 17.8$ & 41.3ะ18.6 & $35.7 \pm 16.9$ & 3P-Weibull & $U$ & 0.139 & 0.3 & 410 \\
\hline Chol (mg/dL) & $191.0 \pm 49.8$ & $195.1 \pm 49.0$ & $187.6 \pm 50.8$ & Normal & $\mathrm{t}$ & 0.459 & 0.2 & 792 \\
\hline
\end{tabular}

25(OH)D, vitamin D; BMI, body mass index; Chol, cholesterol; DBP, diastolic blood pressure; SBP, systolic blood pressure; t, independent t-test; T2DM, type 2 diabetes mellitus; U, Mann-Whitney U-test.

Table 3 Means of 25(OH)D, adjusted for gender and age

\begin{tabular}{|c|c|c|c|c|c|}
\hline \multirow[b]{2}{*}{ Subjects } & \multirow[b]{2}{*}{ Gender } & \multirow{2}{*}{$\begin{array}{l}\text { Adjusted mean } \\
25(\mathrm{OH}) \mathrm{D}, \mathrm{ng} / \mathrm{mL}\end{array}$} & \multicolumn{2}{|l|}{$95 \% \mathrm{Cl}$} & \multirow[b]{2}{*}{ p Value } \\
\hline & & & Lower bound & Upper bound & \\
\hline \multirow[t]{2}{*}{ Controls, $n=35$} & Male, $n=12$ & 40.4 & 30.3 & 50.5 & 0.472 \\
\hline & Female, $n=23$ & 43.6 & 35.6 & 51.5 & \\
\hline \multirow[t]{2}{*}{ Patients with T2DM, $n=41$} & Male, $n=12$ & 36.3 & 24.8 & 47.8 & \\
\hline & Female, $n=29$ & 33.5 & 26.7 & 40.3 & \\
\hline
\end{tabular}

T2DM, type 2 diabetes mellitus.

analysis. A p value $<0.05$ meant a statistically significant result. SBP was transformed via natural logarithm $(\ln )$ in order for the requirements of the GLM to be met.

\section{RESULTS}

Overall, no relationship was found among $25(\mathrm{OH}) \mathrm{D}$, T2DM and use of specific anti-hypertensive agents. A significant relationship existed between $25(\mathrm{OH}) \mathrm{D}$ and SBP.

Table 1 gave the overall demographic details of subjects in the study. Table 2 displayed the characteristics of predictor variables in relation to the total sample size, controls, and patients with T2DM. The calculated effect sizes and sample size estimates for each variable were stated. These estimated sample sizes calculated in the last column of table 2 were not the sample size used in this study. The distributions given were for controls and for patients with T2DM independently. The test statistics used to compare differences between controls and T2DM for the various predictor variables were shown. Table 2 displayed no significant differences in age, body mass index, SBP, DBP, and 25(OH)D between controls and patients with T2DM. Table 3 displayed the means for $25(\mathrm{OH}) \mathrm{D}$ adjusted for age and gender whereby there was no significant difference in $25(\mathrm{OH}) \mathrm{D}$ between patients with T2DM and controls $(\mathrm{p}=0.472)$.

SBP was divided into two categorical variables for SBP $>130$ and $\leq 130 \mathrm{~mm} \mathrm{Hg}$, which were not displayed in a table. The average $25(\mathrm{OH}) \mathrm{D}$ for these categories were $39.3 \pm 19.3$ and $26.5 \pm 11.8 \mathrm{ng} / \mathrm{mL}$, respectively $(\mathrm{p}<0.001$, $25(\mathrm{OH}) \mathrm{D}$ data were log-normal transformed to follow normal distribution). A Mann-Whitney U-test was also
Table 4 GLM output for In (SBP) as a dependent variable

\begin{tabular}{llll}
\hline Source & Significance & $\begin{array}{l}\text { Effect } \\
\text { size (d) }\end{array}$ & $\begin{array}{l}\text { Observed } \\
\text { power (\%) }\end{array}$ \\
\hline Corrected model & 0.006 & 0.4 & 86 \\
T2DM/controls & 0.046 & 0.2 & 52 \\
Gender & 0.558 & 0.1 & 9 \\
$25(\mathrm{OH}) \mathrm{D}>25 \mathrm{ng} / \mathrm{mL}$ & $0.002^{*}$ & 0.4 & 89 \\
\hline
\end{tabular}

${ }^{*} p<0.05=$ statistically significant.

GLM, general linear model; In, natural logarithm; SBP, systolic blood pressure; T2DM, type 2 diabetes mellitus.

applied for the 25(OH)D between the SBP $>130$ and $\leq 130 \mathrm{~mm} \mathrm{Hg}$ categories, which gave a significant difference $(p<0.001)$. There was a moderately positive correlation between SBP and 25(OH)D $\left(r_{s}=0.38, p=0.001\right)$.

Table 4 displayed the results of a GLM univariate analysis applied to $\ln$ (SBP) as a dependent variable with categorical variables T2DM/controls, gender, and $25(\mathrm{OH}) \mathrm{D}(>25$ and $\leq 25 \mathrm{ng} / \mathrm{mL})$ as fixed factors. There was a significant difference between $25(\mathrm{OH}) \mathrm{D}$ levels $>25$ and $\leq 25 \mathrm{ng} / \mathrm{mL}$ for the dependent variable $\ln$ (SBP).

Table 5 displayed the OR, adjusted for age, gender, and T2DM diagnosis, when separating $25(\mathrm{OH}) \mathrm{D}$ and $\mathrm{BP}$ into categorical variables. The $25(\mathrm{OH}) \mathrm{D}$ levels were divided into two categories for concentrations $>30$ and $>25 \mathrm{ng} / \mathrm{mL}$. SBP data were divided into two categories for SBP values $>130$ and $>140 \mathrm{~mm} \mathrm{Hg}$. SBP/DBP data were divided into five categories for SBP/DBP $>130 / 90$, $>130 / 100,>135 / 100,>140 / 80$, and $140 / 90 \mathrm{~mm} \mathrm{Hg}$. 


\begin{tabular}{|c|c|c|}
\hline Blood pressure, mm Hg & $\begin{array}{l}\text { Adjusted OR (95\% Cl) } \\
25(\mathrm{OH}) \mathrm{D}>30 \mathrm{ng} / \mathrm{mL}\end{array}$ & 25(OH)D>25 ng/mL \\
\hline $\mathrm{SBP}>130$ & 4.7 (1.5 to 15.1$) p=0.009^{*}$ & 7.9 (2.2 to 28.7$) p=0.002^{*}$ \\
\hline $\mathrm{SBP}>140$ & $2.0(0.8$ to 5.4$) p=0.157$ & 6.5 (1.8 to 24.2) $p=0.005^{\star}$ \\
\hline SBP/DBP>130/90 & 6.8 (1.8 to 25.4$) p=0.005^{*}$ & 5.5 (1.5 to 19.8$) p=0.009^{*}$ \\
\hline SBP/DBP>130/100 & 5.5 (1.7 to 18.3$) p=0.005^{*}$ & 7.2 (2.0 to 26.0 ) $p=0.003^{*}$ \\
\hline SBP/DBP > 135/100 & 4.0 (1.4 to 11.5$) \mathrm{p}=0.010^{*}$ & 6.2 (1.8 to 22.0$) p=0.004^{*}$ \\
\hline SBP/DBP>140/80 & $2.3(0.9$ to 6.4$) p=0.096$ & 5.8 (1.5 to 21.5$) p=0.009^{*}$ \\
\hline SBP/DBP>140/90 & $2.3(0.9$ to 6.4$) p=0.096$ & 5.8 (1.5 to 21.5$) p=0.009^{*}$ \\
\hline
\end{tabular}

Considering all the BP categories, all the ORs were significantly higher for $25(\mathrm{OH}) \mathrm{D}>25 \mathrm{ng} / \mathrm{mL}$. Regarding 25 $(\mathrm{OH}) \mathrm{D}>30 \mathrm{ng} / \mathrm{mL}$, all the ORs for $\mathrm{BP}$ categories were significantly higher with the exceptions of SBP/DBP $>140 / 80$ and $>140 / 90 \mathrm{~mm} \mathrm{Hg}$. Subjects with SBP above $130 \mathrm{~mm} \mathrm{Hg}$ had the highest odds of having $25(\mathrm{OH})$ $\mathrm{D}>25 \mathrm{ng} / \mathrm{mL}$ (OR 7.9 (2.2-28.7)).

In table $6,25(\mathrm{OH}) \mathrm{D}$ was separated into two concentration categories, $>25$ and $\leq 25 \mathrm{ng} / \mathrm{mL}$. Subjects were divided into categories taking and not taking antihypertensive medication as well as the type of antihypertensive medication used. There was no significant difference $(\mathrm{p}=0.181)$ between the $25(\mathrm{OH}) \mathrm{D}$ categories for patients using and not using antihypertensive medication. The table also displayed that there was no specific antihypertensive that was more associated with a change in $25(\mathrm{OH}) \mathrm{D}$ based on Fisher's exact test $(\mathrm{p}=0.386)$.

Table 6 Contingency table for 25(OH)D categories and antihypertensive therapy

\begin{tabular}{|c|c|c|c|}
\hline Category & $\begin{array}{l}25(\mathrm{OH}) \\
\mathrm{D}>25 \mathrm{ng} / \mathrm{mL}\end{array}$ & $\begin{array}{l}25(\mathrm{OH}) \\
\mathrm{D} \leq 25 \mathrm{ng} / \mathrm{mL}\end{array}$ & $\begin{array}{l}p \\
\text { Value }\end{array}$ \\
\hline $\begin{array}{l}\text { Subjects not on } \\
\text { antihypertensive drug } \\
\text { therapy }\end{array}$ & 25 & 11 & $0.181^{*}$ \\
\hline $\begin{array}{l}\text { Subjects on } \\
\text { antihypertensive drug } \\
\text { therapy }\end{array}$ & 33 & 7 & \\
\hline \multicolumn{4}{|c|}{ Antihypertensive drug used } \\
\hline None & 25 & 11 & $0.386 \dagger$ \\
\hline ACE inhibitors & 14 & 4 & \\
\hline$\beta$-Blockers & 8 & 0 & \\
\hline Diuretics & 1 & 1 & \\
\hline $\begin{array}{l}\text { Calcium channel } \\
\text { blockers }\end{array}$ & 4 & 0 & \\
\hline$\alpha$-Blockers & 3 & 1 & \\
\hline $\begin{array}{l}\text { Angiotensin receptor } \\
\text { blockers }\end{array}$ & 1 & 1 & \\
\hline Other drugs & 2 & 0 & \\
\hline
\end{tabular}

\section{DISCUSSION}

In table 2, the results of the Mann-Whitney U-test for T2DM and controls indicated no significant difference in 25(OH)D between patients with T2DM and controls $(p=0.139)$. After adjustments for gender and age were made, table 2 also indicated no significant differences in 25(O5)D levels between patients with T2DM and controls $(\mathrm{p}=0.472)$. The tropical island of Trinidad, in which the subjects reside, generally has a sunny climate which may account for the production of vitamin D being similar in both groups. Vitamin D is synthesized when sunlight strikes the skin, resulting in the conversion of 7-dehydroxycholesterol to vitamin $\mathrm{D}_{3}{ }^{4}$ Studies have demonstrated that low $25(\mathrm{OH}) \mathrm{D}$ levels are related to T2DM susceptibility; thus, for the Trinidadian population, the problem with the vitamin $\mathrm{D}$ axis is that there may be a problem with the VDR. The VDR gene polymorphism may cause subtle changes in the threedimensional conformation of VDRs. These subtle conformational changes may result in individuals having VDRs with different affinities toward $1,25(\mathrm{OH})_{2} \mathrm{D}$. The differences in affinities may account for an individual's susceptibility toward T2DM. It can be hypothesized then that someone with VDR receptors of low $1,25(\mathrm{OH})_{2} \mathrm{D}$ affinity is susceptible to T2DM. Thus, further investigations are required to elucidate the VDR polymorphisms, which may cause variance in VDRs, in relation to T2DM. This study does not provide conclusive evidence of a relationship existing between VDR and T2DM.

The moderately positive correlation between $25(\mathrm{OH})$ $\mathrm{D}$ and SBP $\left(\mathrm{r}_{\mathrm{s}}=0.38, \mathrm{p}=0.001\right)$ was not expected since a majority of the literature demonstrated either no relationship or an inverse correlation between $25(\mathrm{OH}) \mathrm{D}$ and SBP. ${ }^{10}$ The positive correlation between $25(\mathrm{OH}) \mathrm{D}$ and SBP does agree with a few studies, most of which have small sample sizes. ${ }^{16-19}$ Coupled to this unexpected correlation, patients with $\mathrm{SBP}>130 \mathrm{~mm} \mathrm{Hg}$ were eight times more likely to have a $25(\mathrm{OH}) \mathrm{D}>25 \mathrm{ng} / \mathrm{mL}$. Further investigations in tropical regions are required to determine if these significant findings solely apply to inhabitants in these regions.

The study undertaken did not meet the requirements of the estimated sample size, so it would be noteworthy 
to expand the sample size in order to effectively draw a better conclusion on the correlation between $25(\mathrm{OH}) \mathrm{D}$ and SBP in the Trinidadian population. The GLM univariate analysis displayed in table 4 compensated for the weakness in sample size when considering the $25(\mathrm{OH}) \mathrm{D}$ categories $>25$ and $\leq 25 \mathrm{ng} / \mathrm{mL}$ in relation to $\ln \mathrm{SBP}$ $(\mathrm{p}=0.002,89 \%$ power $)$. The $25 \mathrm{ng} / \mathrm{mL} 25(\mathrm{OH}) \mathrm{D}$ categories were examined in relation to the use of a specific antihypertensive; however, table 6 displayed that there was no significant relationship. This may indicate that antihypertensive medication did not influence a change in vitamin D levels.

The study is a pilot study, which would enable researchers to better determine future sample sizes with sufficient power in relation to a particular outcome variable of interest. There is some obvious complexity in relating T2DM to the vitamin $\mathrm{D}$ axis. Based on current studies and the pilot study conducted, it seems that $25(\mathrm{OH}) \mathrm{D}$ cannot be used as a biochemical marker or predictor for T2DM, but there is some role of vitamin $\mathrm{D}$ in the pathogenesis of T2DM. Further elucidation of the binding interaction of vitamin D to VDR as well as VDR polymorphisms is required to obtain clarity on a possible relationship between T2DM and the vitamin $\mathrm{D}$ axis.

Acknowledgements The authors would like to thank the staff at the Eric Williams Medical Sciences Complex and San Fernando General Hospital, Trinidad and Tobago.

Contributors TGR contributed to the acquisition of data, analysis, manuscript writing, revisions and accuracy of work. SBN contributed to the conception, drafting, integrity of work, sourcing of funding and correspondence. Both the authors contributed to the final version of the article to be published.

Funding This work was supported by the University of the West Indies, St. Augustine Campus (grant number 26600457573).

Competing interests None declared.

Patient consent Obtained.

Ethics approval Campus Ethics Committee of the University of the West Indies.

Provenance and peer review Not commissioned; externally peer reviewed.

Data sharing statement All data collected have been published in the article. Additional genetic data will be produced for a future study; however, DNA extraction has not started. The future genetic analysis, which focuses on the vitamin $\mathrm{D}$ receptor gene polymorphism, will be available to the research team and will be published in a future study.
Open Access This is an Open Access article distributed in accordance with the Creative Commons Attribution Non Commercial (CC BY-NC 4.0) license, which permits others to distribute, remix, adapt, build upon this work noncommercially, and license their derivative works on different terms, provided the original work is properly cited and the use is non-commercial. See: http:// creativecommons.org/licenses/by-nc/4.0/

\section{REFERENCES}

1. Martin T, Campbell RK. Vitamin D and diabetes. Diabetes Spectr 2011;24:113-18.

2. Leahy JL. Pathogenesis of type 2 diabetes mellitus. Arch Med Res 2005;36:197-209.

3. Tang KC, Rury A, Orozco MB, et al. Ultrafast electrocyclic ring opening of 7-dehydrocholesterol in solution: the influence of solvent on excited state dynamics. J Chem Phys 2011;134:104503.

4. Holick MF, Chen TC, Lu Z, et al. Vitamin D and skin physiology: a D-lightful story. J Bone Miner Res 2007;22(Suppl 2):V28-33.

5. Norman AW. From vitamin $D$ to hormone $D$ : fundamentals of the vitamin $\mathrm{D}$ endocrine system essential for good health. Am J Clin Nutr 2008;88:491S-9S.

6. Holick MF, Binkley NC, Bischoff-Ferrari HA, et al. Evaluation, treatment, and prevention of vitamin D deficiency: an Endocrine Society Clinical Practice Guideline. J Clin Endocrinol Metab 2011;96:1911-30.

7. Vieth R. Vitamin D supplementation, 25-hydroxyvitamin D concentrations, and safety. Am J Clin Nutr 1999;69:842-56.

8. Garg M, Lubel JS, Sparrow MP, et al. Review article: vitamin D and inflammatory bowel disease-established concepts and future directions. Aliment Pharmacol Ther 2012;36:324-44.

9. Fitzpatrick TB. The validity and practicality of sun-reactive skin types I through VI. Arch Dermatol 1988;124:869.

10. Pilz S, Tomaschitz A, Ritz E, et al. Vitamin D status and arterial hypertension: a systematic review. Nat Rev Cardiol 2009;6:621-30.

11. Baz-Hecht M, Goldfine AB. The impact of vitamin D deficiency on diabetes and cardiovascular risk. Curr Opin Endocrinol Diabetes Obes 2010;17:113-19.

12. Gress TW, Nieto FJ, Shahar E. Hypertension and antihypertensive therapy as risk factors for type 2 diabetes mellitus. Atherosclerosis risk in communities study. N Engl J Med 2000;342:905-12.

13. National High Blood Pressure Education Program Working Group. National High Blood Pressure Education Program Working Group report on hypertension in diabetes. Hypertension 1994;23:145-58; discussion 159-60.

14. Jarrett RJ, Keen H, McCartney M, et al. Glucose tolerance and blood pressure in two population samples: their relation to diabetes mellitus and hypertension. Int J Epidemiol 1978;7:15-24.

15. Ke L, Mason RS, Kariuki M, et al. Vitamin D status and hypertension: a review. Integr Blood Press Control 2015;8:13-35

16. Kokot F, Schmidt-Gayk H, Wiecek A, et al. Influence of ultraviolet irradiation on plasma vitamin $\mathrm{D}$ and calcitonin levels in humans. Kidney Int Suppl 1989;27:S143-6.

17. Brickman AS, Nyby MD, von Hungen $\mathrm{K}$, et al. Calcitropic hormones, platelet calcium, and blood pressure in essential hypertension. Hypertension 1990;16:515-22.

18. Muray S, Parisi E, Cardús A, et al. Influence of vitamin D receptor gene polymorphisms and 25-hydroxyvitamin $\mathrm{D}$ on blood pressure in apparently healthy subjects. J Hypertens 2003;21:2069-75.

19. Argilés À, Lorho R, Servel MF, et al. Blood pressure is correlated with vitamin D3 serum levels in dialysis patients. Blood Purif 2002;20:370-5. 